\title{
Арсенид-галлиевые структуры с углеродным покрытием: многофункциональное применение для приборов оптоэлектроники и бета-вольтаики
}

В.П. Лесников ${ }^{1}$, М.В. Ведь ${ }^{1}$, О.В. Вихрова ${ }^{1}$, Ю.А. Данилов ${ }^{1}$, П.Б. Демина ${ }^{1}$, Н.В. Дикарева ${ }^{1}$, М.В. Дорохин ${ }^{1}$, Е.Б. Якимов ${ }^{2}$, Б.Н. Звонков ${ }^{1}$, А.В. Здоровейщев ${ }^{1}$, В.А.Ковальский ${ }^{2}$, Р.Н. Крюков ${ }^{1}$

${ }^{1}$ Научно-исследовательский физико-технический институт Нижегородского государственного университета им. Н.И. Лобачевского, Нижний Новгород, 603022, пр. Гагарина, 23/3

${ }^{2}$ Институт проблем технологии микроэлектроники и особочистых материалов Российской академии наук, Черноголовка, 142432 Черноголовка, Московская область, Институтская, 6 тел:+7 (831) 462-31-20, факс:+7 (831) 462-31-36, эл. nочта: vikhrova@nifti.unn.ru

DOI 10.34077/RCSP2021-92

Использование углеродных $(\mathrm{C})$ слоев (однослойного и многослойного графена) для разработки комбинированных с полупроводниками $\mathrm{A}^{3} \mathrm{~B}^{5}$ приборов наноэлектроники затруднено из-за отсутствия подходящих методов формирования С-слоев непосредственно на поверхности полупроводниковых структур с сохранением их свойств.

В данной работе показана возможность получения углеродных нанослоев непосредственно на поверхности GaAs структур методом импульсного лазерного распыления пирографита в вакууме. Для нанесения C-слоев использован лазер YAG:Nd (длина волны 532 нм). Подложка при выращивании поддерживалась при $500^{\circ} \mathrm{C}$, а толщина С-слоя определялась временем испарения и составляла от 4 до 20 нм. По результатам исследований комбинационного рассеяния света и рентгеновской фотоэлектронной спектроскопии полученные углеродные слои представляют собой сплошную пленку нанокристаллического графита, состоящую из зерен многослойного графена. Подобное углеродное покрытие было нанесено на гетероструктуры с квантовой ямой (КЯ) $\operatorname{In}_{x} \mathrm{Ga}_{1-x} \mathrm{As} / \mathrm{GaAs}(x=0.15$, толщина КЯ 8-10 нм) и униполярным легированием всех слоёв (n-типа), а также слаболегированные кремнием $\left(n \sim 6-8 \times 10^{16} \mathrm{~cm}^{-3}\right)$ слои GaAs (толщина $\sim 1-1.5$ мкм). Все полупроводниковые структуры выращены методом MOC-гидридной эпитаксии при $600^{\circ} \mathrm{C}$ на пластинах $n^{+}$-GaAs (100). Изготовленные С-слои являются химически и механически стойкими, имеют $p$-тип проводимости, а на границе раздела с $\mathrm{GaAs}$ формируется потенциальный барьер, при этом само прозрачное углеродное покрытие выполняет роль инжектирующего контакта. Поэтому, несмотря на униполярное легирование GaAs слоёв, изготовленные на основе GaAs-структур с КЯ светодиоды показывали интенсивное электролюминесцентное излучение, наблюдаемое вплоть до 300 К при невысоких токах накачки (2 5 мA). Кроме того, наличие C- слоя на поверхности GaAs структур приводило к появлению высокой фоточувствительности при комнатной температуре в широком диапазоне энергий квантов $1-2.4$ эВ.

Ещё одним потенциальным применением структур со слаболегированным слоем GaAs:Si и C-слоем на поверхности является их использование в качестве основы ячейки на бета-вольтаическом эффекте. Для демонстрации этого был проведён имитационный эксперимент, в рамках которого с использованием электронно-лучевого испарения в вакууме на поверхности структур формировался $\mathrm{TiAu}$ контакт. Изготовленные диоды исследовались методом наведенного тока, в котором ток электронного пучка имитирует генерацию бета-частицы в результате распада, происходящего в контакте, содержащем радиоактивный изотоп (например, TiT $_{2}$ ) [1]. Выполненные имитационные эксперименты и сопутствующие расчёты показали возможность получения плотности тока короткого замыкания для GaAs-структур с C-слоем $\sim 190$ нA/ $\mathrm{cm}^{2}$, что близко к теоретическому пределу для бетавольтаического элемента на основе тритида титана на $\mathrm{GaAs}(219$ нА/см²) [2].

Таким образом, углеродные нанослои, полученные методом импульсного лазерного нанесения, могут иметь многофункциональное применение: во-первых, создание химически и механически прочных проводящих покрытий на поверхности фоточувствительных и светоизлучающих GaAsструктур для приборов оптоэлектроники с улучшенными характеристиками; во-вторых, использование GaAs-структур с С-слоем на поверхности в качестве преобразователей для бета-вольтаических элементов (например, с источником на основе тритида титана).

Работа выполнена при поддержке РФФИ (грант 18-29-19137_мк) и гос.задания (проект 075-03-2020191/5).

\section{Литература}

[1] E.B. Yakimov // Applied Radiation and Isotopes. - 2016. - V.112. - P.98-112.

[2] А.А. Свинцов, Е.Б. Якимов, М.В. Дорохин, П.Б. Демина, Ю.М. Кузнецов // ФТП. 2019. Т.53, вып.1. С.101-103. 